REPORTS OF MORPHOLOGY
$\begin{gathered}\text { Official Journal of the Scientific Society of Anatomists, } \\ \text { Histologists, Embryologists and Topographic Anatomists } \\ \text { of Ukraine } \\ \text { journal homepage: https://morphology-journal.com }\end{gathered}$

\title{
Morphofunctional changes in the lymphoid component of the rats prostate gland in conditions of immunostimulation
}

\section{Evtushenko V.M., Syrtsov V.K., Popko S.S.}

Zaporizhzhia State Medical University, Department of Histology, Cytology and Embryology, Zaporizhzhia, Ukraine

\section{ARTICLE INFO}

Received: 4 December, 2018

Accepted: 9 January, 2019

UDC: 611.637 .018 .24$]-053$

\section{CORRESPONDING AUTHOR}

e-mail: kluchkosv@gmail.com Popko S.S.

\begin{abstract}
To date, the state of the local immune system of the human prostate gland is not sufficiently studied, which prevents in-depth study of sexual disorders and infertility in men, as well as its common diseases: hypertrophy, adenoma, cancer. In order to study the morphological state of the lymphoid apparatus of the prostate of rats on the background of immunostimulation, 60 rat prostate glands were studied by histological, morphometric and statistical methods. Using the methods of variation statistics, we assessed the correctness of the distribution of signs for each of the obtained variation series, the average values for each attribute that was studied, standard errors and standard deviations. The reliability of differences in values between independent micrometric values with a normal distribution of signs was determined by the Student's criterion. The paper describes the patterns of formation of the local immune system of the prostate gland in the experiment after the introduction of immunoglobulin in adult male rats Wistar line. It was revealed that in rats after administration of immunoglobulin, the formation of lymphoid structures was observed three days earlier than in intact and control rats. First appear lymphoid formations in the stroma of the prostate gland, in the blood vessels - perivascular lymphoid nodules. By the end of the first week, lymphoid structures are formed in the glandular epithelium of the prostate gland-lymphoepithelial nodules. In lymphoid structures, the content of lymphocytes in all periods exceeds the benchmarks with the maximum changes on day 7 of the study. Reactive changes in the capillary endothelium in close relationship with the restructuring of lymphoid nodules during antigenic stimulation indicate that they are redundant in providing immune homeostasis. Thus, against the background of immunostimulation, changes occur in the local immune system of the prostate gland, manifested in an increase in the number of immunocompetent cells, the formation of lymphoid nodules, and are accompanied by corresponding changes in the hemomicrocirculatory bed.

Key words: prostate gland, immunostimulation, lymphoid component.
\end{abstract}

\section{Introduction}

Functional and morphological features of the human prostate gland are an important problem in connection with the spread of its diseases, in the pathogenesis of which there are violations of specific and nonspecific mechanisms of protection [1, 4, 6, 7, 8, 26]. Lack of knowledge about the morphofunctional changes of the prostate gland and virtually no studies aimed at studying the morphological substrate of local nonspecific immune responses, prevents in-depth study of sexual disorders and infertility in men, as well as its common diseases: hypertrophy, adenomas, cancer $[13,17$, 25, 29].

Existing data do not allow us to formulate the general patterns of prostate morphogenesis and to determine the role of its lymphoid formations in the formation of nonspecific and specific mechanisms of protection in the norm and pathology $[2,3,5,9,10,11,12]$.

So we took for a purpose to investigate the morphological condition of the rat prostate lymphoid apparatus on the background of immunostimulation.

\section{Materials and methods}

As objects of the study, 60 prostate glands of sexually mature male rats (obtained from the vivarium of the Institute of Pharmacology and Toxicology, Academy of Medical Sciences of Ukraine, Kyiv) weighing 220-240 g (age 5-6 months) were taken. 
The experimental animals were divided into three groups: the first group was intact animals (10 rats), the second group was experimental (40 rats), and the third group was control (10 rats). The three groups were in the same conditions. The research followed international rules and principles of the "European Convention for the Protection of Vertebrate Animals Used for Experiments and Other Scientific Purposes" (Strasbourg, 1986) and the "General Ethical Principles of Animal Experiments" (Kyiv, 2001) and Law of Ukraine №3447 "On the Protection of Animals from Cruelty" - IV dated 21.02.2006.

Experimental animals were intramuscularly injected with human normal immunoglobulin at a dose of $1 \mathrm{mg}$. Immunoglobulin is characterized by high antigenic activity and no toxic, pyrogenic, adjuvant effect. Controls were rats administered saline at equivalent doses. Given the presence of circadian rhythms in the lymphoid organs, slaughter of rats was performed at the same time of day. Euthanasia of rats was performed with an overdose of thiopental anesthesia on $3,7,14,21$ days with the observance of the "Rules for working with experimental animals".

Serial paraffin sections, 5-6 $\mu \mathrm{m}$ thick, stained with hematoxylin and eosin, were prepared for the study. The sections after staining were enclosed in polystyrene under the coverslip and examined in a light microscope. Morphological examination of the obtained sections was performed using an Olimpus microscope "PrimoStar" FL "ILED" with digital microphotography using Olimpus Soft (2011).

Among the elements of the lymphoid tissue of the prostate, the average number of immunocompetent cells was calculated: lymphocytes, plasmocytes, macrophages.

Quantitative analysis of the results of the morphometric study and statistical processing of the morphometric data were performed according to conventional statistical methods and using the programs "Microsoft Office Excel" and "Statistica 6.1". Using the methods of variational statistics, the correctness of the distribution of traits by each of the variations obtained, the average values for each trait studied, standard errors and standard deviations were evaluated. The significance of the difference of values between independent micrometric values in the normal distribution of features was determined by a paired two tailed Student's test.

\section{Results}

The prostate gland of rats is represented by a complex of glandular formations: ventral, dorsal lobes and coagulation glands, the dimensions of which are 10-12 x 7-9 mm, 6-8 $x$ 5-6 mm, 8-12 x 4-6 mm. The parenchyma of the organ consists of the alveolar-tubular glands, the epithelium of which is represented by secretory and basal cells.

The formation of lymphoid clusters occurred through the migration of lymphocytes from the blood vessels. Lymphoid clusters consisted of small and medium lymphocytes, 60$70 \%$ of which belong to thymus-dependent lymphocytes.
The composition of lymphoid clusters varied from 4 to 7 days after the experiment. Reticular cells, macrophages, and plasma cells appeared among the lymphoid cells. Detected lymphoblasts with figures of mitosis in the nuclei. Due to the proliferation of lymphoid cells, perivascular lymphoid nodules developed on the basis of lymphoid clusters (Fig. 1). Intramuscular administration of antigen near the blood vessels and prostate gland area increased the number of lymphoid formations.

From the beginning of the experiment, the number of lymphoid formations associated with blood vessels decreased with the increase of its term, and in the area of the glandular epithelium increased. The cellular composition of lymphoid formations after the introduction of gammaglobulin changed most sharply at 3-7 days (Table 1).

As a result of antigenic stimulation on the third day increased migration of lymphocytes. Lymphocytes, for the most part, were located diffusely under the glandular epithelium in the experimental group, and single lymphocytes were observed in similar places in animals of control group. At this time, the number of blast cell forms of lymphocytes increased markedly (compared to the control group). Macrophage contacts with lymphocytes are monitored. The cells form figures in the form of sockets, in the center of which there is a macrophage, and around it there are lymphocytes.

The preferred site of blast localization for the third day after immunization is lymphoid clusters near the blood vessels. In these areas blasts form clusters of 5-6 cells in the field of view, in the control group of animals, these cells are virtually undetermined. The presence of macrophages and close contacts with them precursors of plasma cells indicate that the interaction of macrophages and lymphocytes is necessary not only at the time of initiation of immune response.

The formation of reproductive centers in the lymph nodes of the prostate of rats begins after 3-5 days after immunization, subsequently in them the proliferation of cells occurs, which leads to an increase in the size of the

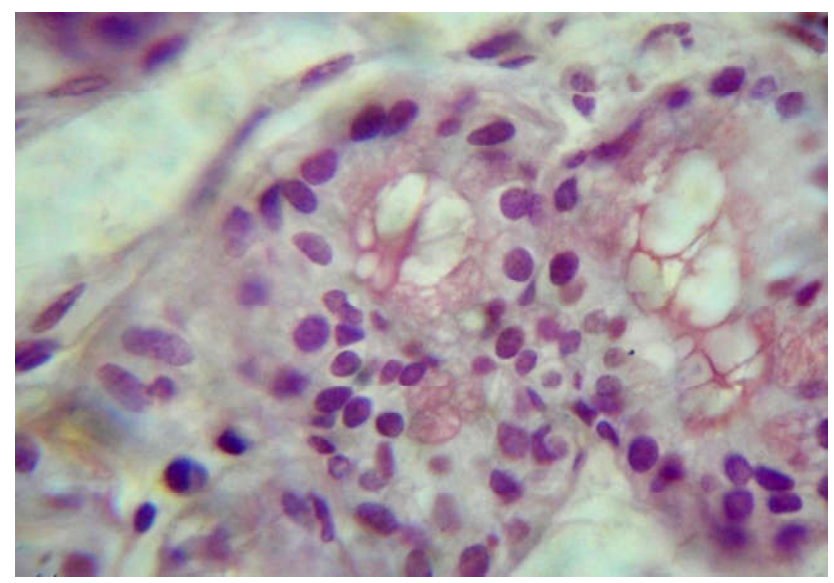

Fig. 1. Prostate gland of a mature rat for 7 days after immunization. Hematoxylin-eosin. x600. 
Evtushenko V.M., Syrtsov V.K., Popko S.S.

Table 1. Percentage ratio $(X \pm S x)$ of cells in rats prostate lymphoepithelial nodules after single administration of gamma globulin.

\begin{tabular}{|c|c|c|c|c|c|}
\hline \multirow{2}{*}{ Cells } & \multirow{2}{*}{ Control group } & \multicolumn{4}{|c|}{ Day of experiment } \\
\cline { 3 - 6 } & & 3 & 7 & 14 & 21 \\
\hline Small lymphocytes & $32.05 \pm 3.05$ & $18.03 \pm 3.05$ & $14.07 \pm 1.02$ & $12.04 \pm 2.05$ & $12.01 \pm 1.02^{*}$ \\
\hline Medium lymphocytes & $59.02 \pm 6.01$ & $66.00 \pm 4.02$ & $66.05 \pm 5.02$ & $69.01 \pm 3.06$ & $70.04 \pm 4.06^{*}$ \\
\hline Lymphoblasts & $6.024 \pm 1.022$ & $9.045 \pm 0.501$ & $10.2 \pm 0.48$ & $12.03 \pm 0.50$ & $10.06 \pm 0.72^{*}$ \\
\hline Plasmocytes & $2.062 \pm 0.506$ & $4.026 \pm 0.501$ & $6.035 \pm 0.305$ & $6.036 \pm 0.245$ & $7.066 \pm 0.201^{*}$ \\
\hline Macrophages & $1.027 \pm 0.308$ & $3.066 \pm 0.203$ & $3.045 \pm 0.208$ & $1.022 \pm 0.102$ & $1.045 \pm 0.201^{*}$ \\
\hline
\end{tabular}

Notes: ${ }^{*}$ - $p<0.05$ compared to control.

reproductive center and the formation of other zones of lymphoid structures. Changes in the cellular composition of perivascular lymphoid nodules after antigenic stimulation are largely similar to those in lymphoepithelial nodes.

On the seventh day after antigenic exposure in the lymphoepithelial nodules in the subepithelial zone was observed increased migration of lymphocytes to the epithelium, which is represented by different cell forms and can be attributed to the stratified cuboidal epithelium. In lymphoepithelial nodes, in addition to this zone, there are 2 more zones. Darker is the peripheral area, which consists of tightly adjacent small lymphocytes. This zone in the form of a "hat" covers the central zone.

It should be noted the different nature of the processes that occur at 5-7 days in the reproduction centers after antigenic stimulation. In the latter there is a fairly homogeneous picture: blasts predominate in the dark zone (and it is the origin of the breeding center). Some of them are mitotically divided.

Due to proliferation, lymphoid structures spread towards the glandular epithelium. The content of reticular cells and lymphoblasts increased, and plasma cells appeared. A large number of macrophages are observed on the seventh day after immunization in reproduction centers, where plasmablasts and young plasmocytes are in close relationship with macrophages.

By the end of the second week (on the 14th day), all the zones were clearly visible in the lymph nodes. In the central area of the lymphoepithelial nodules, the highest number of mitoses was observed. In the peripheral zone, the content of plasma cells and small lymphocytes increased. In the subepithelial zone, the number of phagocytic macrophages increased in the cytoplasm which contained the remains of lymphocyte nuclei. These cells were surrounded by lymphocytes, reminiscent of immune sockets described in immunological studies. In the subepithelial area, compared to the control, the percentage of small lymphocytes increased, and the average lymphocytes decreased, reticular cells appeared, the number of macrophages increased.

On the twenty-first day with the introduction of normal doses of antigen, the structure and cellular composition of lymphoid structures differed little from the controls. In some lymph nodes, the reproduction centers subjected to reverse development. Destructive changes were detected in individual lymphocytes.

The lumen of the lymphatic vessels and venules was filled with small lymphocytes. After antigenic stimulation in the early stages of the experiment, on the 2-4 days was determined the expansion of the inter-endothelial contacts of the blood capillaries of the lymphoepithelial nodes. Near the apical edge of the endothelial cells, cracks were found, the localization of which apparently corresponded to the loci of increased permeability. Of particular importance in the barrier function of the prostate gland are the blood vessels located near the lymphoid formations and in the stroma of the prostate gland. The change in cellular composition in the lymphoid nodules of the rat prostate after antigenic stimulation causes specific cytoarchitectonics of the hemomicrocirculatory bed. It is established that the area occupied by different links of the microcirculatory bed of lymph nodes increases with antigen loading. The lumen of the blood capillaries increases and migration through the capillaries and postcapillary venules of lymphocytes and plasma cells increases.

Specific changes in the capillary wall, along with the reticular cells of the lymph nodes of the prostate, play an important role in the cell rearrangement of lymphoid structures and the formation of their specific microenvironment. Reactive changes in capillary endothelium in close relationship with the restructuring of lymphoid nodules during antigenic stimulation indicate their reserve capacity for immune homeostasis.

During antigenic load venules also undergo certain changes. The wall of venules is lined by endothelium, whose morphology varies depending on the phase of the immune response. In the early stages, when there is an increased influx of lymphocytes to the lymph nodes, endothelial cells are hypertrophied, take the form of prismatic epithelium, and lymphocytes through the wall of venules are evicted into the surrounding tissue. Sometimes venules acquire the character of post-capillary venules with high endothelium. In the early stages of the immune response, the number of macrophages and lymphocytes increases, neutrophil and eosinophil granulocytes appear. At the height of the immune response there are many cells of the plasma row at different stages of maturation, macrophages with phagocytosed cellular elements in the venules. The increase in the area occupied by the various units of the microcirculatory bed 
indicates an increase in intercellular and intracellular transport of substances.

\section{Discussion}

Therefore, we assume that the revealed topographic proximity of lymphoid formations with glands at the level of excretory ducts is due to the protective role of lymphocytes in cases of antigens penetration at this site, and close microtopographic relations with the terminal divisions provides one of the mechanisms of immune responses products of immune responses, which are then included in the secretion of the glands, which has been proven in several works $[14,15,16,18]$. Considering the changes in the local immune system of the prostate, one cannot ignore the large individual variability in the amount of lymphoid tissue in it. Such a picture can be due to different lifestyles, different antigenic effects of the environment, different reactivity of the body. More significant range of fluctuations from the minimum to the maximum numbers is usually observed during the period of greatest development of lymphoid tissue, the formation of nodules in it.

For lymphoid tumors of the prostate, the structures of the microenvironment are the glandular epithelium, the components of the reticular tissue and the cells of the walls of the microvessels. The formation and glandular epithelium, development and transformation of the microcirculatory bed units are closely related and interdependent with the reaction of the perivascular connective and reticular tissue, with the formation of its cellular and fibrous structures [19, 20, 22].

Considering the lymphoid structures of the prostate as a morpho system, that is, a complex of structurally and functionally interconnected elements that form a single integral system, we can distinguish the basic patterns of their morphogenesis.

First, the development of lymphoid structures in the prostate occurs under the influence of natural antigenic stimulation in pre- and post-natal ontogeny.

Second, the formation of lymphoid structures is closely linked to the level of development, both in the glandular epithelium and in the stroma of the prostate and reticular components of the stroma and vascular system in it.

Third, the development of lymphoid structures of the prostate has a stage character and is determined by interstitial and intercellular interactions.

In our opinion, we can distinguish the following stages of development of lymphoid structures of the prostate:

- during the first stage loose clumps of lymphoid cells are formed. In this area of the connective tissue of the prostate, histochemical changes are associated with the formation of the stroma of the lymphoid clusters, and its own vascular bed begins to form. These processes play an important role in the preparation of microenvironment;

- the second stage is characterized by a gradual increase in the number of lymphocytes and cells of the monocyte row, their diffuse distribution, the appearance of mitotic activity. The vascular bed of lymphoid nodules is being differentiated, in which, in addition to capillaries, arterial and venular vessels appear. In the venular branch, there are specialized areas with high endothelium required for lymphocyte recycling. Occur further changes in the stroma associated with an increase in reticular fibers and the formation of a thin capsule;

- in the third stage, the processes of genesis of lymphoid nodules are stabilized, which is manifested by the absence of pronounced morphological changes;

- the fourth stage is characterized by the reverse development of the lymph nodes of the prostate and involutive processes in them, typical for the organs of the immune system.

Thus, we first discovered the features of the structure of lymphoid prostate formation, which are expressed in the high saturation of all prostate structures diffusely located lymphoid cells and lymphoid nodules of different sizes and stages of development, which have a peculiar organization and are in close relationship with the epithelial and stromal structures of the prostate.

Analysis of the data on the morphogenesis of the lymphoid structures of the prostate indicates that they develop as peripheral organs of the immune system and participate in both local and general immune reactions. Carrying out a detailed study of the development of lymphoid structures of the prostate of rats in normal and after exposure to the antigen, due to the need to confirm the characteristics of the organization and function of the lymphoid formations of the prostate of a human, revealed by them, their connection with histogenetic processes in the prostate, as well as to determine the genesis factors of lymphoid apparatus prostate [21, 24, 27].

Therefore, we first obtained data on the formation of a local prostate immune system in an experiment after intramuscular injection of immunoglobulin into mature Wistar rats. In rats, after intramuscular administration, immunoglobulin formation was observed to occur three days earlier than intact and control rats. Lymphoid formations initially appear in the stroma of the prostate gland, near the blood vessels - perivascular lymph nodes. By the end of the first week, the formation of lymphoid structures in the area of the glandular epithelium of the prostate - lymphoepithelial nodes appears. In lymphoid structures, the content of lymphocytes in all periods exceeds the control values.

The work carried out is the basis for the development of a new direction for the further study of age-related changes in the cellular composition and histophysiology of prostate tissue, to create models of organ functioning in norm and pathology and to develop on this basis rational methods of correction of hormonal homeostasis, organ secretion and regulation of fertility. The results of this work open a new direction in the study of prostate morphogenesis in normal and experiment, in age and evolutionary aspects, which is important for the development of a modern understanding of the mechanisms of formation of the prostate tissue systems in ontogeny. 
In the future it is planned to continue the study of morphogenesis of lymphoid structures of the prostate of rats by immunohistochemical studies.

\section{Conclusions}

1. Formation of the prostate's own lymphoid apparatus in rats occurs by the migration of lymphocytes from the blood vessels.

2. On the background of immunostimulation, the

\section{References}

1. Attard, G., Parker, C., Eeles, R. A., Schröder, F., Tomlins, S. A., Tannock, I. ... de Bono, J. S. (2016). Prostate cancer. Lancet, 387, 70-82. https://doi.org/10.1016/S0140-6736(14)61947-4.

2. Brechka, H., McAuley, E. M., Lamperis, S. M., Paner, G. P., \& Vander, Griend, D. J. (2016). Contribution of caudal Müllerian duct mesenchyme to prostate development. Stem Cells Dev. 25, 1733-1741. doi: 10.1089/scd.2016.0088.

3. Chen, M., Yeh, C.-R., Shyr, C.-R., Lin, H.-H., Da, J., \& Yeh, S. (2012). Reduced prostate branching morphogenesis in stromal fibroblast, but not in epithelial, estrogen receptor alpha knockout mice. Asian J. Androl. 14, 546-555. doi: 10.1038/ aja.2011.181.

4. Choi, N., Zhang, B., Zhang, L., Ittmann, M., \& Xin, L. (2012). Adult murine prostate basal and luminal cells are self-sustained lineages that can both serve as targets for prostate cancer initiation. Cancer Cell, 21, 253-265. doi: 10.1016/ j.ccr.2012.01.005.

5. Chua, C. W., Shibata, M., Lei, M., Toivanen, R., Barlow, L. J., Bergren, S. K. ... Shen, M. M. (2014). Single luminal epithelial progenitors can generate prostate organoids in culture. Nat. Cell Biol., 16, 951-961. doi: 10.1038/ncb3047.

6. Corn, P. G., Wang, F., McKeehan, W. L. \& Navone, N. (2013). Targeting fibroblast growth factor pathways in prostate cancer. Clin. Cancer Res., 19, 5856-5866. doi: 10.1158/10780432.CCR-13-1550.

7. DeGraff, D. J., Grabowska, M. M., Case, T. C., Yu, X., Herrick, M. K., Hayward, W. J. ... Matusik, R. J. (2014). FOXA1 deletion in luminal epithelium causes prostatic hyperplasia and alteration of differentiated phenotype. Lab. Invest., 94, 726-739. doi: 10.1038/labinvest.2014.64.

8. Ferraldeschi, R., Sharifi, N., Auchus, R. J., \& Attard, G. (2013). Molecular pathways: Inhibiting steroid biosynthesis in prostate cancer. Clin. Cancer Res., 19, 3353-3359. doi: 10.1158/10780432.CCR-12-0931.

9. Gamat, M., Malinowski, R. L., Parkhurst, L. J., Steinke, L. M., \& Marker, P. C. (2015). Ornithine decarboxylase activity is required for prostatic budding in the developing mouse prostate. PLOS ONE1. doi: e0139522 10.1371/journal.pone.0139522.

10. Gevaert, T., Lerut, E., Joniau, S., Franken, J., Roskams, T., \& De Ridder, D. (2014). Characterization of subepithelial interstitial cells in normal and pathological human prostate. Histopathology, 65, 418-428. 10.1111/his.12402.

11. Grabowska, M. M., Elliott, A. D., DeGraff, D. J., Anderson, P. D., Anumanthan, G., Yamashita, H., ... Matusik, R. J. (2014). NFI transcription factors interact with FOXA1 to regulate prostatespecific gene expression. Mol. Endocrinol., 28(6), 949-964. doi: 10.1210/me.2013-1213.

12. Höfner, T., Eisen, C., Klein, C., Rigo-Watermeier, T., Goeppinger, S. M., Jauch, A. ... Trumpp, A. (2015). Defined conditions for the isolation and expansion of basal prostate progenitor cells of mouse and human origin. Stem Cell Reports, 4(3), 503- formation of lymphoid structures is noted three days earlier than in intact and control rats. Initially, lymphoid lesions appear in the stroma of the prostate gland, near blood vessels - the perivascular lymph nodes. By the end of the first week, lymphoid structures are forming in the prostate gland glandular epithelium.

3. In lymphoid structures of the prostate of experimental animals the content of lymphocytes in all periods exceeds the control values.

518. doi: 10.1016/j.stemcr.2015.01.015.

13. Ittmann, M., Huang, J., Radaelli, E., Martin, P., Signoretti, S., Sullivan, R. ... Cardiff, R. D. (2013). Animal models of human prostate cancer: the consensus report of the New York meeting of the Mouse Models of Human Cancers Consortium Prostate Pathology Committee. Cancer Res., 73(9), 2718-2736. doi: 10.1158/0008-5472.CAN-12-4213.

14. Karthaus, W. R., laquinta, P. J., Drost, J., Gracanin, A., van Boxtel, R., Wongvipat, J. ... Clevers, H. C. (2014). Identification of multipotent luminal progenitor cells in human prostate organoid cultures. Cell, 159(1), 163-175. doi: 10.1016/ j.cell.2014.08.017.

15. Keil, K. P., Abler, L. L., Mehta, V., Altmann, H. M., Laporta, J., Plisch, E. H. ... Vezina, C. M. (2014). DNA methylation of Ecadherin is a priming mechanism for prostate development. Dev. Biol., 387, 142-153. doi: 10.1016/j.ydbio.2014.01.020.

16. Kwon, O. J., \& Xin, L. (2014). Prostate epithelial stem and progenitor cells. Am. J. Clin. Exp. Urol., 2, 209-218.

17. Kwon, O. J., Zhang, L., Ittmann, M. M. \& Xin, L. (2014). Prostatic inflammation enhances basal-to-luminal differentiation and accelerates initiation of prostate cancer with a basal cell origin. Proc. Natl. Acad. Sci. USA 111, E592-E600. doi: 10.1073/ pnas. 1318157111.

18. Kwon, O.-J., Zhang, L., \& Xin, L. (2016). Stem Cell Antigen-1 identifies a distinct androgen-independent murine prostatic luminal cell lineage with bipotent potential. Stem Cells, 34, 191-202. doi: 10.1002/stem.2217.

19. Lee, D.-K., Liu, Y., Liao, L., Wang, F., \& Xu, J. (2014). The prostate basal cell $(\mathrm{BC})$ heterogeneity and the p63-positive BC differentiation spectrum in mice. Int. J. Biol. Sci. 10, 10071017. doi: 10.7150/ijbs.9997.

20. Lee, S. H., Johnson, D. T., Luong, R., Yu, E. J., Cunha, G. R., Nusse, R. \& Sun, Z. (2015). Wnt/beta-catenin-responsive cells in prostatic development and regeneration. Stem Cells, 33, 3356-3367. doi: 10.1002/stem.2096.

21. Luo, W., Rodriguez, M., Valdez, J. M., Zhu, X., Tan, K., Li, D., Siwko, S., Xin, L., \& Liu, M. (2013). Lgr4 is a key regulator of prostate development and prostate stem cell differentiation. Stem Cells, 31, 2492-2505. doi: 10.1002/stem.1484.

22. Peng, Y.-C., Levine, C. M., Zahid, S., Wilson, E. L., \& Joyner, A. L. (2013). Sonic hedgehog signals to multiple prostate stromal stem cells that replenish distinct stromal subtypes during regeneration. Proc. Natl. Acad. Sci. USA 110, 20611-20616. doi: 10.1073/pnas.1315729110.

23. Popko, S. S., \& Yevtushenko, V. M. (2018). Features of the PSA Expression by human prostate gland structures. Morphologia, 12(3), 123-126. doi: https://doi.org/10.26641/19979665.2018.3.123-126

24. Syrcov, V. K. (2017). Ultrastructural features of the epithelial component of the human prostate gland in the prenatal period of ontogenesis. World of Med. and Biol., 2 (60), 153-156. 
25. Shibata, M., \& Shen, M. M. (2015). Stem cells in geneticallyengineered mouse models of prostate cancer. Endocr. Relat. Cancer, 22, T199-T208. doi: 10.1530/ERC-15-0367.

26. Siegel, R. L., Miller, K. D., \& Jemal, A. (2016). Cancer statistics, 2016. CA Cancer J. Clin., 66, 7-30. doi: 10.3322/caac.21332.

27.Szczyrba, J., Niesen, A., Wagner, M., Wandernoth, P. M., Aumüller, G., \& Wennemuth, G. (2017). Neuroendocrine cells of the prostate derive from the neural crest. J. Biol. Chem., 292, 2021-2031. doi: 10.1074/jbc.M116.755082.
28. Trotsenko, B. V., \& Luhyn, Y. A. (2009). Regional heterogeneity of mesenchyme in the processes of prostate gland morphogenesis in human and rat fetuses. Morphologia, III(3), 126-130.

29. Watson, P. A., Arora, V. K., \& Sawyers, C. L. (2015). Emerging mechanisms of resistance to androgen receptor inhibitors in prostate cancer. Nat. Rev. Cancer, 15, 701-711. doi: 10.1038/ nrc4016.

\section{МОРФОФУНКЦІОНАЛЬНІ ЗМІНИ ЛІМФОЇДНОГО КОМПОНЕНТА ПЕРЕДМІХУРОВОЇ ЗАЛОЗИ ЩУРІВ В УМОВАХ ІМУНОСТИМУЛЯціЇ}

Євтушенко, В.М., Сирцов, В.К., Попко С.С.

На сьогоднішній день стан локальної імунної системи передміхурової залози людини є недостатньо дослідженим, що перешкоджає поглибленому вивченню статевих розладів і безпліддя у чоловіків, а також їі поширених захворювань: гіпертрофрії, аденоми, раку. Мета роботи - вивчити морфологічний стан лімфоїдного апарату передміхурової залози щурів на тлі імуностимуляції. За допомогою гістологічних, морфометричних та статистичних методів дослідження були вивчені 60 передміхурових залоз щурів. Оцінили правильність розподілу ознак за кожним із отриманих варіаційних рядів, середні значення за кожною вивченою ознакою, стандартні помилки та стандартні відхилення. Достовірність різниці значень між незалежними мікрометричними величинами при нормальному розподілі ознак визначали за критерієм Cm'юдента. $B$ роботі охарактеризовані закономірності фрормування локальної імунної системи передміхурової залози в експерименті після внутрішньом'язового введення імуноглобуліну у статевозрілих щурів лінії Вістар. Виявлено, що у щурів після введення імуноглобуліну лімфоїдні структури фоормуються на три доби раніше, ніж у інтактних і контрольних тварин. Спочатку з'являються лімфоїдні утворення в стромі передміхурової залози, а біля кровоносних судин - периваскулярні лімфоїдні вузлики. До кіния першого тижня лімфоїдні структури фрормуються в області залозистого епітелію передміхурової залози - лімфоепітеліальних вузликів. У лімфоїдних структурах вміст лімфоцитів в усі періоди перевищує контрольні показники з максимальними змінами на 7 добу дослідження. Реактивні зміни ендотелію капілярів в тісному взаємозв'язку з перебудовою лімфроїдних вузликів при антигенній стимуляції вказують на їх резервні можливості у забезпеченні імунного гомеостазу. Таким чином, на тлі імуностимуляції відбуваються зміни в локальній імунній системі передміхурової залози, котрі проявляються у збільшенні кількості імунокомпетентних клітин, фрормуванні лімфоїдних вузликів, і супроводжуються відповідними змінами гемомікроциркуляторного русла.

Ключові слова: передміхурова залоза, імуностимуляція, лімфоїдний компонент.

\section{МОРФОФУНКЦИОНАЛЬНЫЕ ИЗМЕНЕНИЯ ЛИМФОИДНОГО КОМПОНЕНТА ПРЕДСТАТЕЛЬНОЙ ЖЕЛЕЗЫ КРЫС В УсловияХ ИммУностимУляции \\ Евтушенко В.М., Сырцов В.К., Попко С.С.}

На сегодняшний день состояние локальной иммунной системы предстательной железы человека исследовано недостаточно, что препятствует углубленному изучению половых расстройств и бесплодия у мужчин, а также ее распространенных заболеваний: гипертрофии, аденомы, рака. Цель работы - изучить морфологическое состояние лимфоидного аппарата предстательной железы крыс на фоне иммуностимуляции. С помощью гистологических, морфометрических и статистических методов исследования были изучены 60 предстательных желез крыс. Оценили правильность распределения признаков по каждому из полученных вариационных рядов, средние значения по каждому изученному признаку, стандартные ошибки и стандартные отклонения. Достоверность различий значений между независимыми микрометрическими величинами при нормальном распределении признаков определяли по критерию Стьюдента. В работе охарактеризованы закономерности формирования локальной иммунной системы предстательной железы в эксперименте после введения иммуноглобулина у половозрелых крыс линии Вистар. Выявлено, что у крыс после введения иммуноглобулина лимфоидные структуры формируются на трое суток раньше, чем у интактных и контрольных животных. Сначала появляются лимфоидные образования в строме предстательной железы, а возле кровеносных сосудов - периваскулярные лимфроидные узелки. К концу первой недели лимфоидные структуры фрормируются в области железистого эпителия предстательной железы - лимфоэпителиальных узелков. В лимфоидных структурах содержание лимфоцитов во все периоды превышает контрольные показателями с максимальными изменениями к 7 суткам исследования. Реактивные изменения эндотелия капилляров в тесной взаимосвязи с перестройкой лимфоидных узелков при антигенной стимуляции указывают на их резервные возможности в обеспечении иммунного гомеостаза. Таким образом, на фоне иммуностимуляции происходят изменения в локальной иммунной системе предстательной железы, проявляющиеся в увеличении количества иммунокомпетентных клеток, формировании лимфоидных узелков, и сопровождаются соответствующими изменениями гемомикроциркуляторного русла.

Ключевые слова: предстательная железа, иммуностимуляция, лимфоидный компонент. 